\title{
障害のデータベース入カの手法
}

\section{2. 障害のデータベース入力の手法一脳卒中の維持期}

東京都リハビリテーション病院リハビリテーション科 山田深

慶應義塾大学医学部リハビリテーション医学教室 里宇 明元

2000 年に介護保険が導入され 3 年の歳月が流れた. 介護保険の基本理念の一つとしてリハ ビリテーション（以下，リハ）による要介護状態の軽減,・予防の重視があげられており, 脳 卒中維持期において，リハが担ってゆくべき役割は大きい．維持期においては，1）十分なリ 八を受け, 獲得された機能の維持が必要な症例, 2) リハが不十分なまま，在宅または施設入 所に至った症例，3）一度獲得された機能が廃用や疾病の発生・増悪等により低下した症例が 混在していると考えられるが，その実態は明らかではなく，効果的な介入方法も確立してい ない，限られた医療・保健・福祉の資源を有効に活用し，最大限の効果をあげるためには， 対象者の情報を共通尺度による評価をもとにデータベース化し，実態を明らかにするととも に, 維持期リハにおける具体的な介入方法とその効果に関するエビデンスを蓄積していくこ とが不可欠である．維持期リハにおいては，脳血管障害に関する基本情報，再発の危険因子， 併存疾患の有無, 機能障害や能力低下, さらに社会的環境を含めた介護負担感, 生活関連動 作や QOL の評価，リハの経緯，介護福祉サービスの利用状況などをデータとして集積してい く必要がある。急性期, 回復期からの評価と併せ, 介護負担感の尺度である Burden Interview（Zarit）や，生活関連動作の尺度である Frenchay Activities Index（FAI）, QOL を評 価する Short Form-36 などを総合的に組み合わせたデータセットをもとに，いわゆる「仮の 要介護状態」等, 改善が見込める問題点を効率的にスクリーニングし, ゴールを定めたリハ アプローチが行われることが望ましい. 維持期リハデータベースのシステム設計においては, このように多面的で多岐にわたるデータを長期にわたって管理する必要がある。そのために は煩雑なデータの圥長性を排除し, 必要かつ十分なデー夕項目をいかに設定するか, 維持期 リハに関わる多くの職種が共用できるユーザーインターフェースをいかに構築できるかが問 われる。しかし，在宅ケアアセスメントにおける百家争鳴の状態に見られるように，現在は 試行錯誤の段階であり，科学に裏付けられたリ八医学のリーダーシップが求められている. 在宅ならびに入所施設, 医療機関など, 維持期り八の現場は多種多様である. 急性期, 回復 期からの流れを含め, それぞれの特性を生かした効率的な連携システムが求められている現 在, 標準化された評価項目にもとづいたデータセットを作成し, リハニーズに合わせた運用 をはかることが不可欠である，発表では，われわれが試作したデータベースを紹介するとと もに今後の方向性について言及したい. 